\author{
Visión Electrónica \\ Más que un estado sólido \\ https://doi.org/10.14483/issn.2248-4728
}

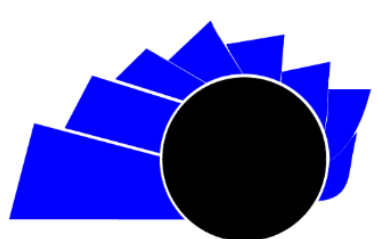

VISIÓN ELECTRÓNICA

\title{
Analysis of temperature control effect in fluidized bed coffee roaster
}

\author{
Análisis del efecto del control de la temperatura en una tostadora de café de lecho \\ fluido
}

Diego Andrés Campo-Ceballos ${ }^{\left(\mathbb{D}_{1}\right.}$, Kevin Jancarlo Barco-Sotelo ${ }^{\left(\mathbb{D}_{2}\right.}$, Hector Fabian Dorado-Ipia ${ }_{3}$,
Carlos Alberto Gaviria-López ${ }_{4}$

INFORMACIÓN DEL ARTÍCULO

Historia del artículo:

Enviado: 18/10/2020

Recibido: 29/10/2020

Aceptado: 24/11/2020

\section{Keywords: \\ CAD Design \\ Coffee Industry 4.0 \\ Digital Control \\ Fluidized Bed \\ SCAA}

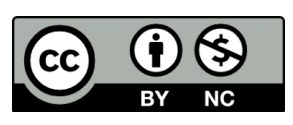

Palabras clave:

Diseño CAD

Industria del café 4.0

Control digital

Lecho fluido

SCAA

\begin{abstract}
One of the main sources of economic income in Colombia's agricultural sector is the marketing of coffee with a high contribution to the country's economy. However, trends in coffee industry 4.0 show that the coffee roasting process is where more value aggregation is presented and at the same time is one of the most complex because multiple factors are involved such as grain moisture, volume, variety and heat and mass transfer variables. The main objective of this work was to design and implement a fluidized bed system for the study of the effect of temperature control on the physical properties of roasted coffee from Cauca-Colombia. The development of the work was addressed in 4 sequential phases: CAD design, Digital manufacture, temperature control design and the systems analysis. The proposed fluid bed system features a control system for the RoR (rate of rise) that can be adjusted between 3 to $20^{\circ} \mathrm{C} / \mathrm{min}$, and provide a prediction in the events of the standard roasting profile (Turning Point, Yellow, First Crack, Development time, Second Crack, Drop).
\end{abstract}

\begin{abstract}
RESUMEN
Una de las principales fuentes de ingresos en el sector agropecuario de Colombia es la comercialización del café con un alto aporte a la economía del país. Sin embargo, las tendencias de la industria 4.0 del café muestran que el proceso del tostado es donde más agregación de valor existe, pero es uno de los más complejos. Aquí, intervienen factores variables como por ejemplo la humedad del grano, el volumen, la variedad, y las relacionadas con transferencia de calor y masa. El objetivo principal de este trabajo fue desarrollar un sistema de lecho fluido para el estudio del efecto del control de temperatura sobre las propiedades físicas del café tostado del Cauca-Colombia. El trabajo se abordó en 4 fases secuenciales. Diseño CAD, Fabricación digital, Control de temperatura y el análisis del sistema. El tostador integra un sistema de control para el RoR (rate of rise) que puede ser ajustado entre 3 a $20^{\circ} \mathrm{C} / \mathrm{min}$, y proporciona un seguimiento a los eventos de la curva de tostado (retorno, amarillamiento, primer Crack, desarrollo, Segundo Crack, descarga).
\end{abstract}

${ }^{1}$ Physics Engineering, Unicauca, Colombia. MSc. Mechatronics systems, UnB-Brasil. PhD. (c) Electronics Sciences, Unicauca, Colombia. Current position: Associate professor Unicomfacauca. GISI. E-mail: dcampo@unicomfacauca.edu.co

2 BSc. in Mechatronics Engineering, Unicomfacauca, Colombia. Grupo GISI. E-mail: kevinbarco@unicomfacauca.edu.co

${ }^{3}$ BSc. in Mechatronics Engineering, Unicomfacauca, Colombia. Grupo GISI. E-mail: hectordorado@unicomfacauca.edu.co

${ }^{4}$ BSc. in Electronics Engineering, Unicauca, Colombia. PhD. Advance automation \& Robotics- UPC, Spain. Current position: Full Profesor FIET-Unicauca, Colombia. E-mail: cgaviria@unicauca.edu.co 


\section{Introduction}

In Colombia and in tropical Latin American countries, a large part of the economy depends on coffee [1]. About 30\% of washed Arabic coffee in the world is produced by Colombia, and it is the largest producer of quality coffee worldwide due to its environmental conditions, management system and quality, they are part of the differential elements of Colombian coffee [2]. According to the reports for the years 2007-2013, Colombia has 13 departments with a trend of stability in coffee production, giving the department of Cauca as the fourth producer [3]. Chemically coffee is made up of water and dry matter. The dry matter of almond coffee beans is made up of minerals and organic substances that are carbohydrates, lipids, proteins, alkaloids, such as caffeine and trigonelline, as well as carboxylic and phenolic acids, and volatile compounds that give the aroma of almonds. [4]. Two variables are handled in roasting: temperature and time. According to these two variables, several types of roast can be obtained with the same coffee, in addition to graphing the roast curves that can predict the qualities of a coffee in the cup. It is necessary to take into account that, to elaborate a roast curve or profile, the temperatures recorded in fixed intervals of time must be noted until the final product is obtained, accompanied by other data such as: origin, density, type of coffee, percentage moisture, initial weight, final weight [5].

Mechanical roasters were introduced in the mid1900s, in the United States of America and in Germany. The difference between one piece of equipment and another is the way in which the energy is supplied to start roasting (conduction, convection and radiation) and the roast capacities range from fifty grams to four tons per hour [6]. In the industry there are currently various equipment that allows toasting, this equipment is classified according to their mechanical principle of operation. In the horizontal rotary drum roaster, the coffee is roasted in a rotating cylindrical container, which induction heats the coffee bean. The Coffee Roaster QUANTIK is an example of the solutions provided by the market in terms of coffee roasters in Colombia. It is specially designed for coffee quality control laboratories [7]. Secondly, the static vertical drum roaster has a roasting system for this type of machine is to rotate blades that agitate the coffee bean, mounted on a vertical axis with continuous rotation [8].

Taking these factors into account, for the fluid bed roaster the coffee beans are heated, and levitated by a flow of air at elevated temperatures. Heating and cooling are carried out in the same chamber. They present the best heat transfer since the grains are in direct contact with the hot air. This type of roasters has been the subject of study in recent years [9].

The main objective of this work was to develop a fluid bed system to study the effect of temperature control on the physical properties of roasted coffee from CaucaColombia [10]. Automatic control integrated into digital manufacturing has played an important role in the technological advancement of the coffee industry and the manufacture of new products [11]. In the design of the control, there are different configurations in the linear dynamics of the controller, so it is commonly represented by a block diagram. The PID controller provided a signal to the process with a proportional, integral and derived combination of the actuation signal, allowing the analysis and monitoring of roasted coffee samples [12] [13].

\section{Materials and methods}

To carry out the development of the work, the mechatronic design methodology was implemented under the VDI 2206 standard formulated by the German engineering society, through this methodology the development of devices with a feedback loop that allows to verify the correct operation of the devices developed are based on the design of the system through the use of CAD tools: phase 1. Design, phase 2. Simulation, which allow reducing errors and costs in the construction process. Phase 3: Taking into account the rebound effect on heat transfer [14], an air accumulation system was designed to maintain pressure and speed, all of this designed and simulated using CAD design tools and experimentally validated as can be seen in figures 1 and 2. To determine the fluid velocity, equation (1) was used.

$$
\mathrm{V}=\frac{\mathrm{M}}{\mathrm{A}}
$$

Where $\mathrm{V}$ is the fluid velocity, $\mathrm{M}$ the manufacturer's data flow in $\mathrm{m}^{3} / \mathrm{s}$ and (A) the area of the ducts. Substituting the real values, the velocity is equal to 37.5 $\mathrm{m} / \mathrm{s}$. Meanwhile, the simulation yielded a speed of 40 $\mathrm{m} / \mathrm{s}$ and a linear behavior, as seen in Figure 2.

The process of validation of the simulated results was carried out by building the duct system for the fluid previously designed in the CAD software, taking the measurement of the height reached by the particles within the fluid bed container. Having a stable fluid source, the next phase was the implementation of the heating system inside the structure designed for the circulation of the hot air fluid, the communication circuit, data reception and the construction of the fluid bed container. 
Figure 1. Fluid velocity within the chamber and ducts.

IDWORKS MBD | Flow Simulation |

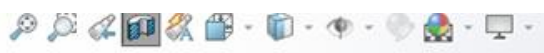

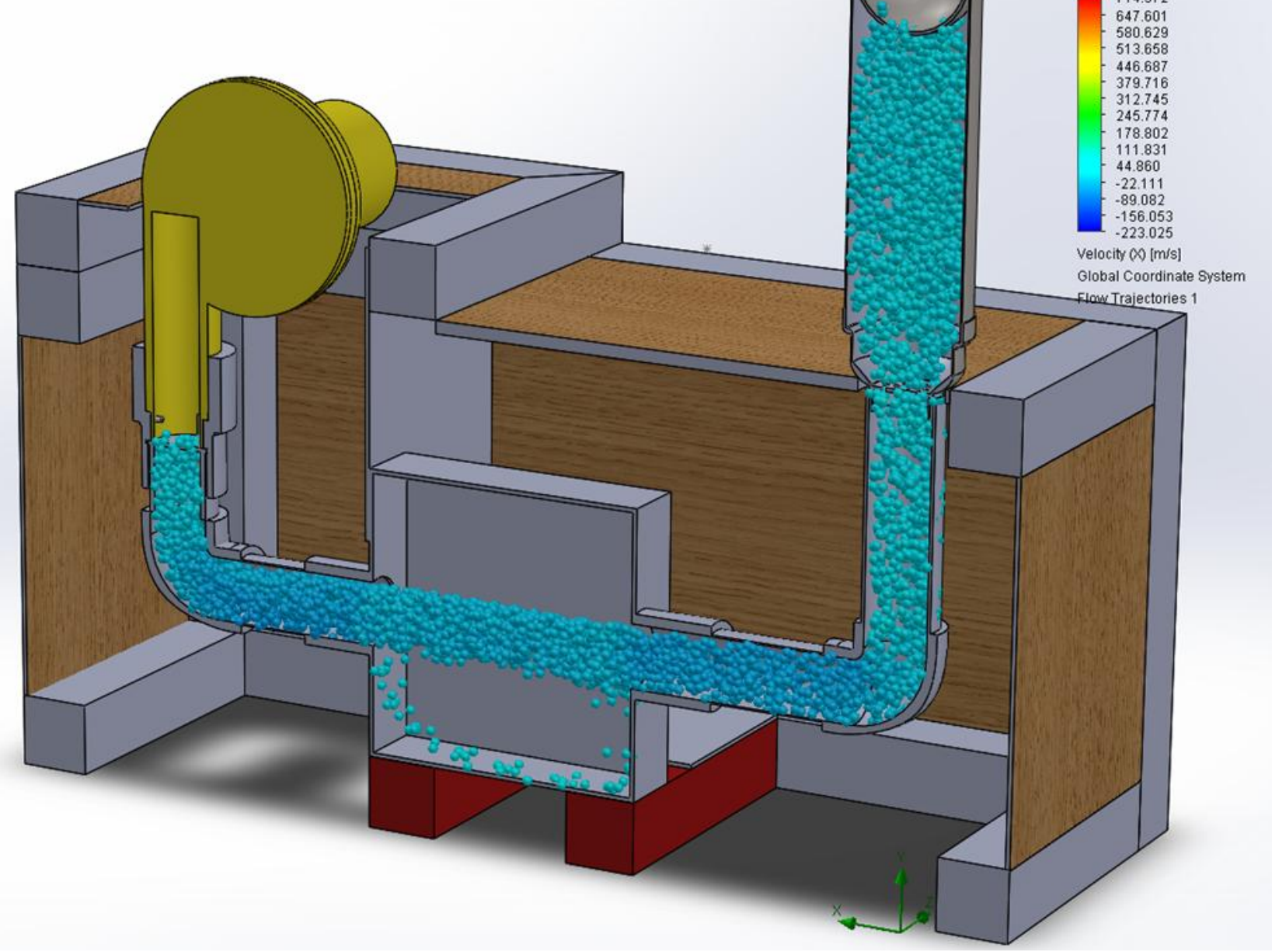

Source: own.

Figure 2. Heat generating element and toasting container.

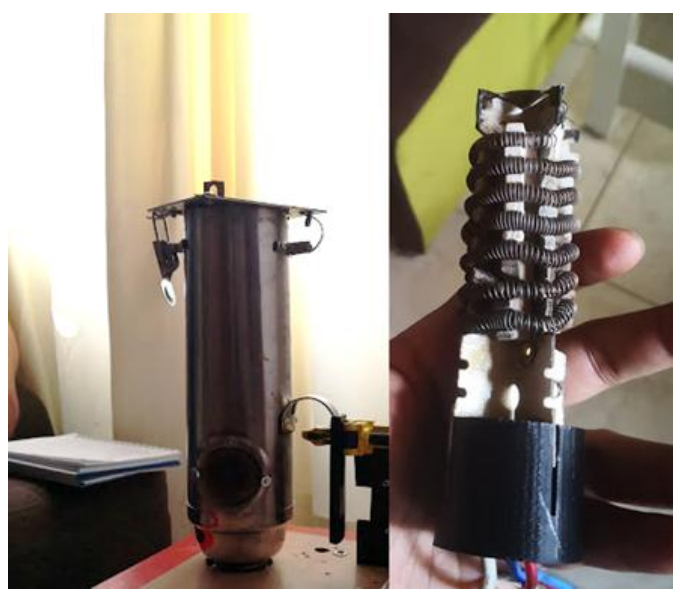

Source: own.
Figure 3. Graphic user interface in LABVIEW software.

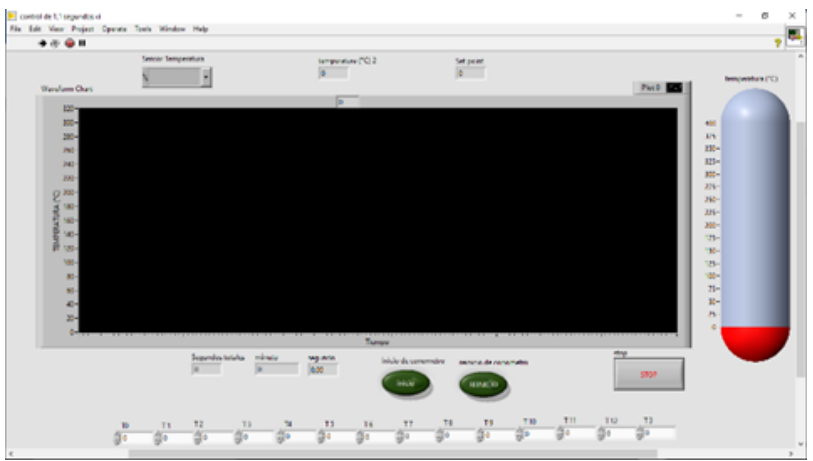

Source: own.

With the fluid bed container built, the sensing and communication circuit, and the properly positioned 
heating element, it is necessary to perform the data acquisition interface and the implementation of communication protocols. For the design of the data acquisition and sending interface, the LabVIEW 2017 industrial software was used, as shown in Figure 3.

With the developed interface it is possible to acquire the plant data in such a way that it is possible to carry out the identification process or mathematical model and design of the temperature controller. The profile curves of roasted coffee were obtained through the interface.

Figure 4. Plant behavior.

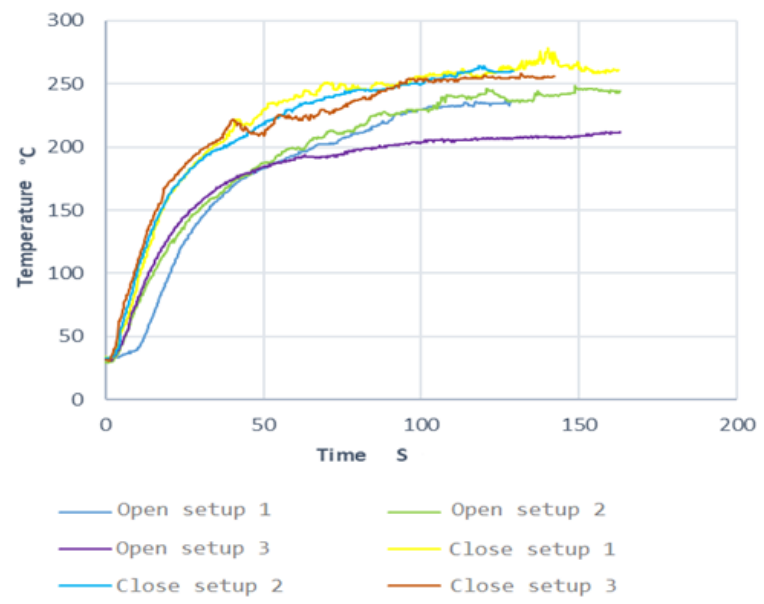

Source: own.

With the data of curves of figure 4 it was possible to carry out the identification process of the mathematical model that governs the device and, in this way, to develop a temperature controller. In order to carry out an identification process with the highest level of precision, MATLAB software was used for this process as is shown in figure 5 .

Figure 5. Measured and step predicted output.

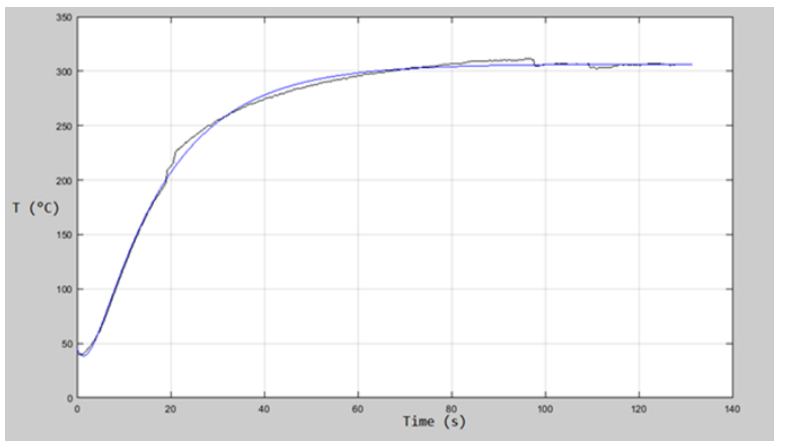

Source: own.
The transfer function was obtained and shown in equation (2)

$$
G(s)=\frac{0.05038}{s^{2}+0.8884 s+0.04765}
$$

Equation 2, presents a precision of $95.6 \%$ with respect to the sampled data, due to the precision offered by this mathematical model the decision was made to implement a first controller, to propose the option of adding a zero or one more pole to increase the precision of the mathematical model. With the identified transfer function, it was transferred to the discrete space using the $\mathrm{z}$ transform in equation (3)

$$
G\left(z^{-1}\right)=\frac{-0.1075 z^{-1}+0.5742 z^{-2}}{1-1.3799 z^{-1}+0.4113 z^{-2}}
$$

Then the controller was carried out, to determine the control model, the mathematical formulas that govern the PID RST control design are taken as a reference.

$$
H(s)=\frac{G e^{-T t s}}{T 2 s+1} o H(s)=\frac{W 0^{2} e^{-T t s}}{s^{2}+2 \mathfrak{z} W 0 s+W 0^{2}}
$$

Where $z$ is the damping coefficient that governs the response signal of the control system, W0 refers to the natural frequency with which the control is going to behave, Ts refers to the sampling time of the variable to be controlled, $\mathrm{T}$ is a delay time, $\mathrm{T} 2$ is a time constant. According to the design criteria for a PID RST controller, equation (5) was obtained.

$$
H(s)=\frac{1.1219}{s^{2}+4.2389 s+1.1219}
$$

With equation (5) we proceeded to move to the discrete space, so that, like the transfer function of the plant, the same procedure is also carried out, in equation (6) the new equation is shown.

$$
\left(z^{-1}\right)=\frac{-1.5668 z^{-1}+0.739 z^{-2}}{1-0.772 z^{-1}+0.0144 z^{-2}}
$$

With equation (3) and equation (6) finally found, we proceed to relate them by means of equation (7), which allows us to translate the $\mathrm{z}$ transform in the state space, so that a microprocessor can interpret the mathematical information transferred. 


$\left[\begin{array}{l}1 \\ s 1 \\ r 0 \\ r 1 \\ r 2\end{array}\right]=\left[\begin{array}{ccccc}1 & 0 & 0 & 0 & 0 \\ 1.7103 & 0.9721 & -0.0159 & 0 & 0 \\ 5.1168 & 2.3143 & 1.3154 & -0.0215 & 0 \\ 1.7677 & 1.0158 & -0.0166 & 1.3535 & 0.0221 \\ -0.0333 & -0.0189 & 0 & 0 & 1.3532\end{array}\right]\left[\begin{array}{c}1 \\ -1.3799 \\ 0.4113 \\ 0 \\ 0\end{array}\right]$

(7)

$$
\left[\begin{array}{c}
1 \\
s 1^{\prime} \\
r 0 \\
r 1 \\
r 2
\end{array}\right]=\left[\begin{array}{c}
1 \\
0.3624 \\
2.4643 \\
0.3592 \\
-0.0071
\end{array}\right]
$$

With the result of equation (8), we proceeded with the calculation of the RST polynomials that will be implemented in a closed loop with the plant to validate the operation of the control, using MATLAB Simulink tool, initially the operation of the controller was checked by matching the polynomials $\mathrm{R}=\mathrm{T}$ applying a step input (see figure 6).

Figure 6. Block diagram for controller simulation.

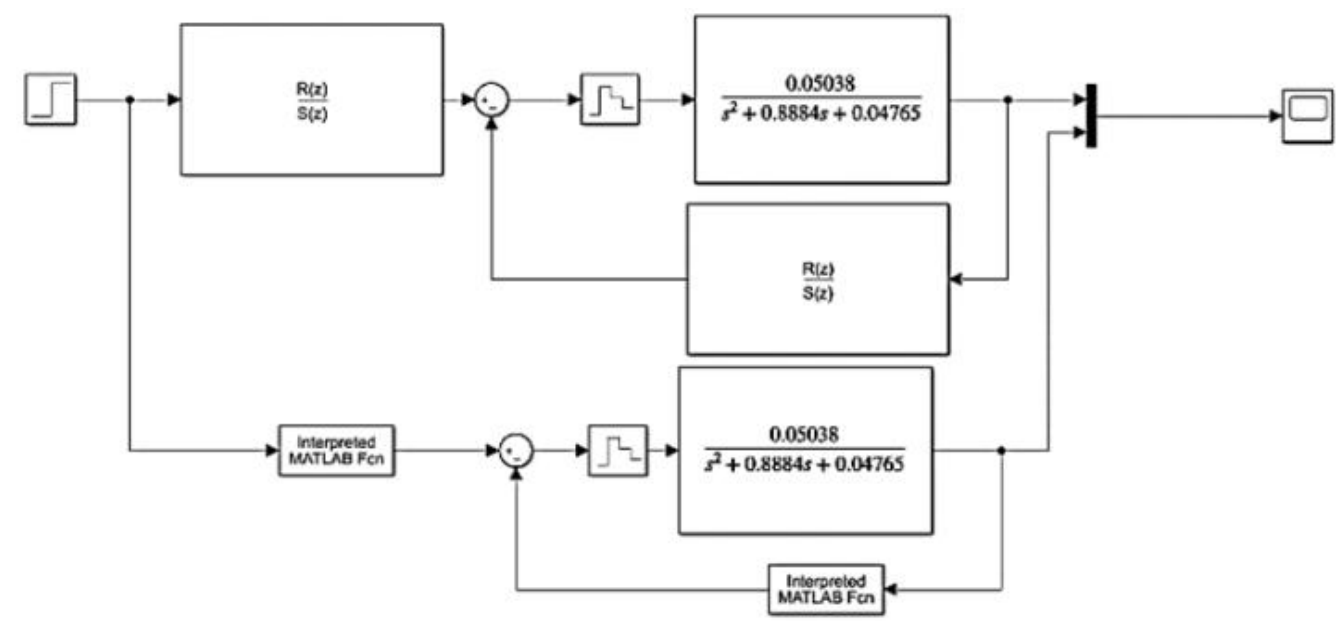

Source: own.

Figure 7. Response of the programmed controller compared to the controller in polynomial form.

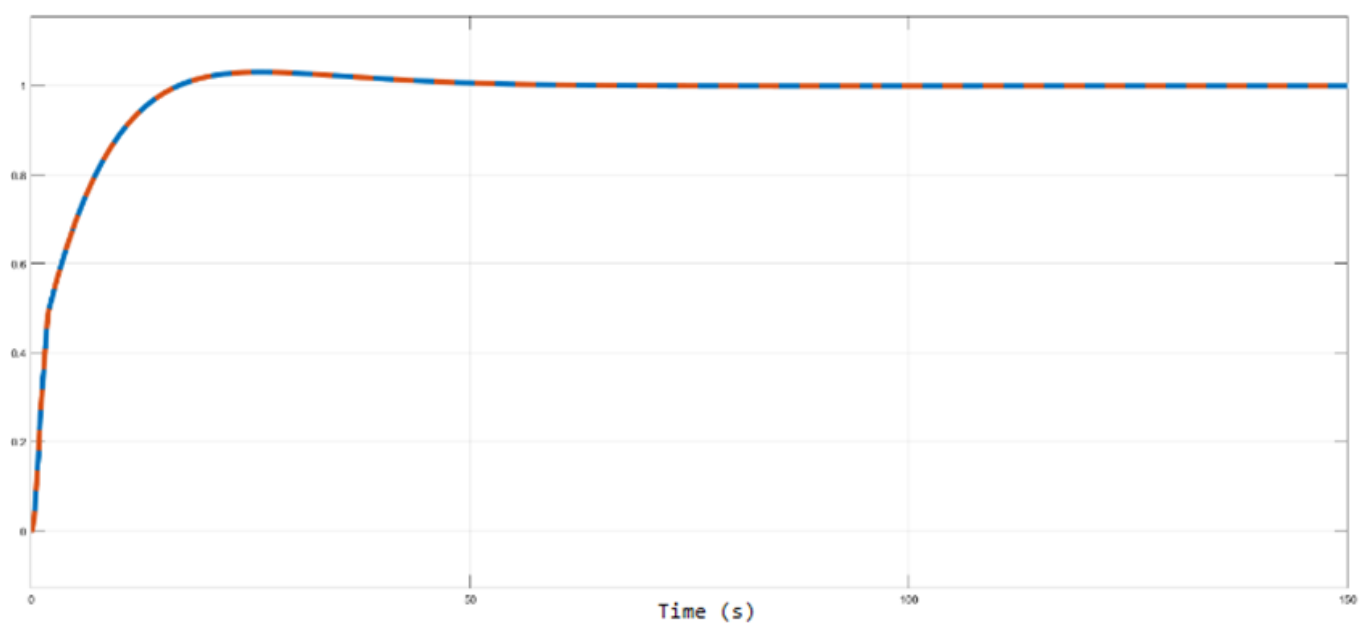

Source: own.

The simulation of the controller implementation contrasted with the controller in the form of polynomials can be seen in figure 7 , where the responses are parallel and very close $(<5 \%)$, thus guaranteeing that the 
controller programmed in the microcontroller will have the behavior of response graphed in simulation.

Once the correct operation of the controller had been validated by means of the equations in the state space, the programming was carried out in the microcontroller to study the behavior of the temperature control through the data collected through the graphical interface, obtaining the results of the graph.

\section{Results and discussion}

With the control incorporated into the fluid bed system, 6 roasted coffee samples were taken to validate the behavior of the previously designed controller. Six coffee roasts (profiles) were done with a programmed roast profile, they were carried out in order to validate the behavior of the controller, the stability and the ability to follow a programmed curve. In Figure 8, the results of the 6 roasted samples are presented. With the data recorded through the graphical interface, the first step is to identify if descriptive statistical methods can be applied according to their normality, the identification of the type of data was carried out through the IBM SPSS Software, thanks to which it was possible to find, on the one hand, the following graphs that represent the percentage of precision second by second within a roasting process and, on the other, it was defined that the data are not normalized by means of the Kolmogorov Smirnov test, which is why it is necessary to perform an analysis not Kruskal Wallistype parametric.

Figure 8. Temperature control comparison of roasting profiles.

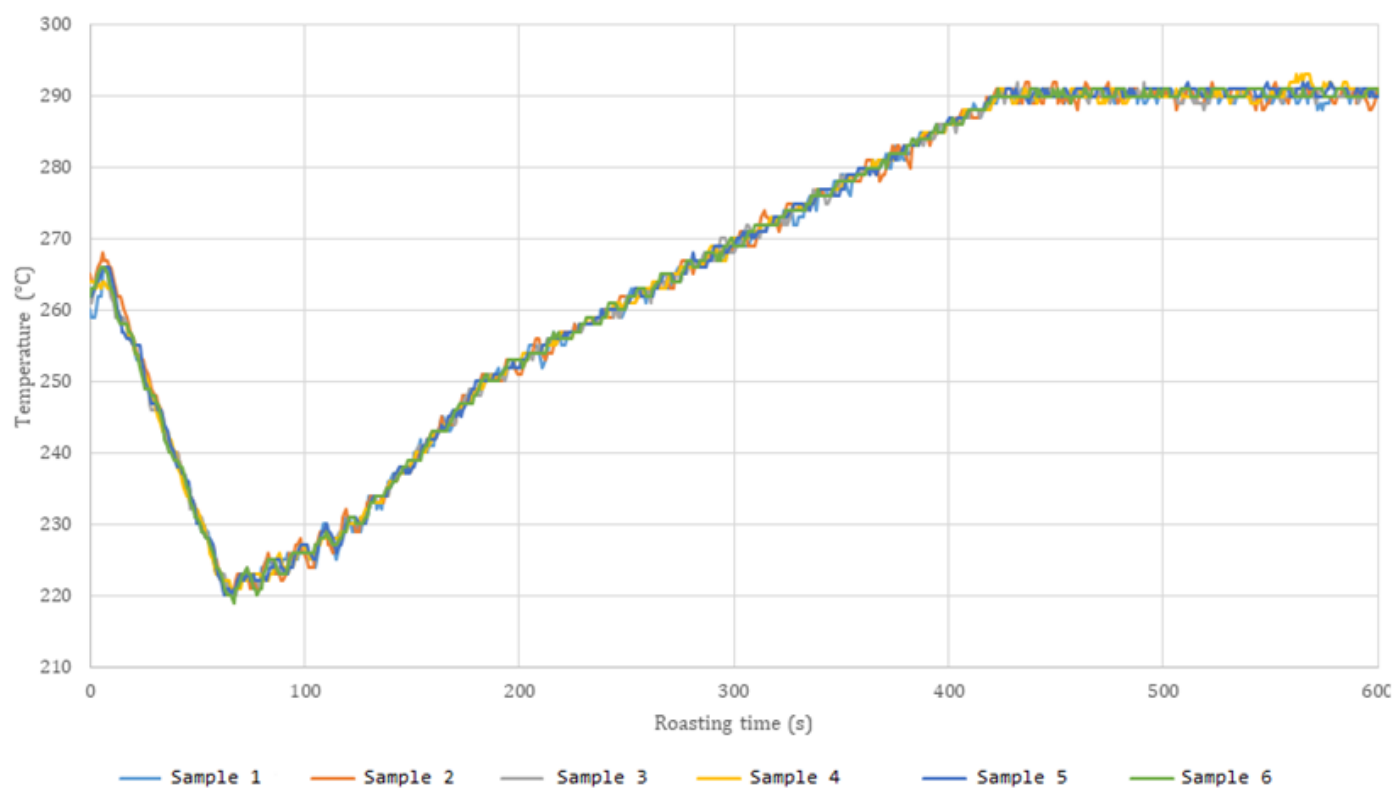

Source: own.

Table 1. Data normalization test.

\begin{tabular}{|c|c|c|c|}
\hline \multirow{2}{*}{ ROASTING DATA } & \multicolumn{3}{|c|}{ Kolmogorov-Smirnova } \\
\cline { 2 - 4 } & statistics & gl & Sig. \\
\hline Sample 1 &, 189 & 601 &, 000 \\
\hline Sample 2 &, 208 & 601 &, 000 \\
\hline Sample 3 &, 207 & 601 &, 000 \\
\hline Sample 4 &, 204 & 601 &, 000 \\
\hline Sample 5 &, 244 & 601 &, 000 \\
\hline Sample 6 &, 201 & 601 &, 000 \\
\hline
\end{tabular}

Source: own 
In the groups in figure 9 , it is possible to observe the minimum level of precision of $97.5 \%$ with a sampling time of one second, however, in order to determine the similarity between the different curves, it is necessary to implement the Kruskal Wallis analysis. that allows to carry out the comparison of non-normalized data groups and to be able to obtain a more precise point of view about the operation of the controller, to facilitate the understanding of the comparisons, the samples were divided into two groups, thus obtaining the results of figure 10 and figure 11.

Figure 9. Controller precision.
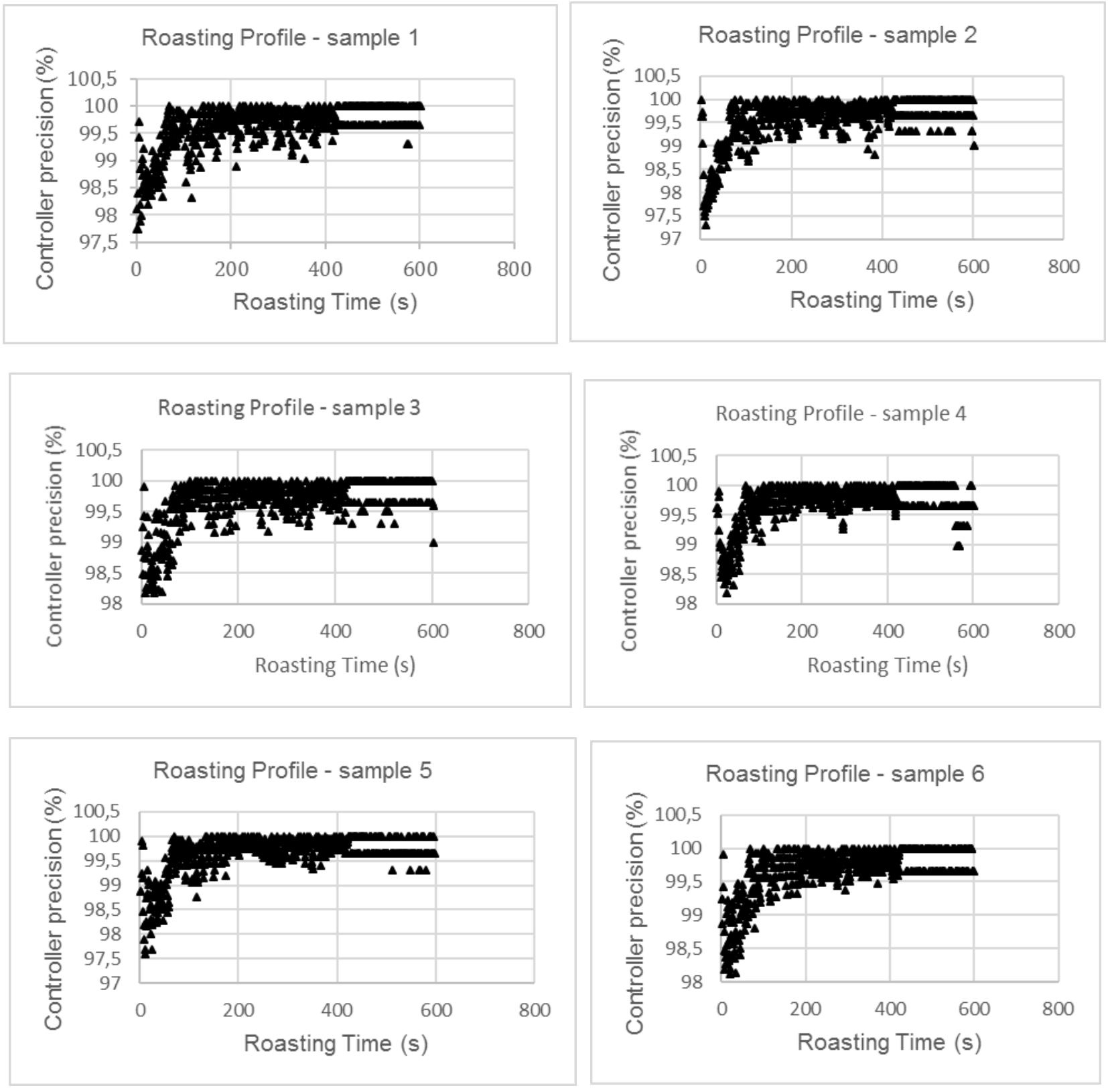

Source: own. 
Figure 10. Kruskal Wallis Comparative analysis profiles 1 to 3 from SPSS IBM.

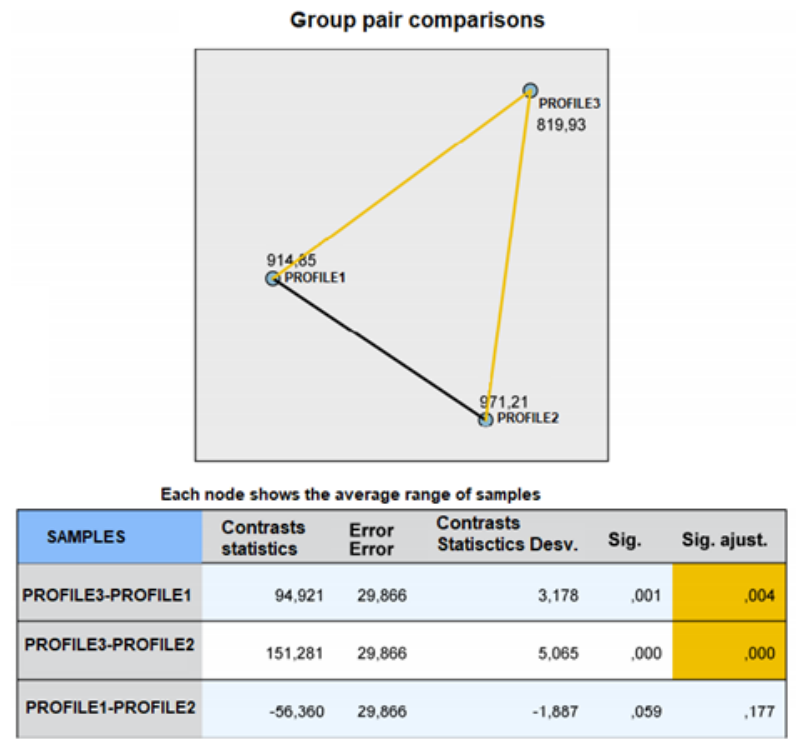

Source: own.

Figure 11. Kruskal Wallis Comparative analysis curves 4 to 6 from SPSS IBM.

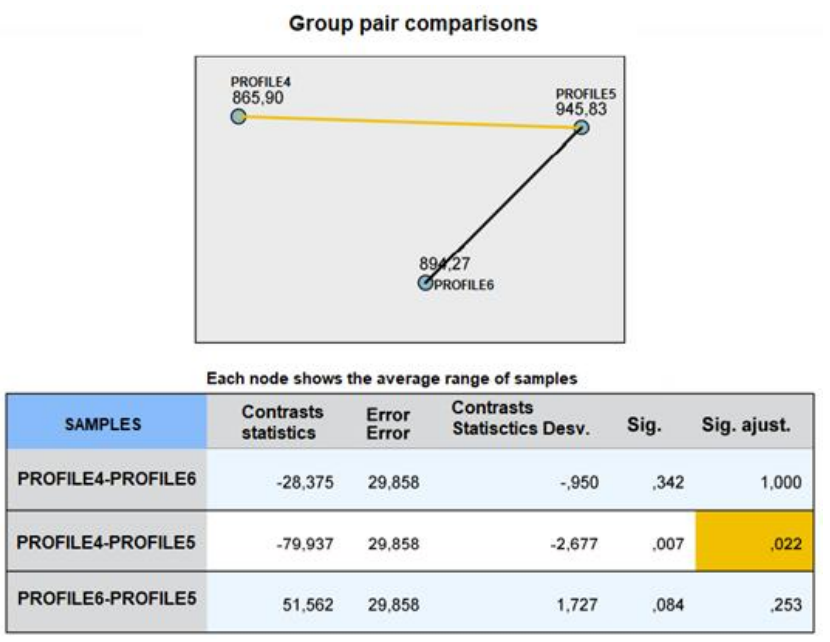

Source: own.

In figure 10, it can be seen that there is a greater level of difference of curves 1 and 2 with respect to curve 3 with the highest contrast statistic, thus the level of significance is less than 0.05 margin of error to accept the hypothesis that there is a significant difference between the different roasting curves [15]. Coffee industry and, in general, food security requires this kind of research and development to transfer and adopt technology that makes the rural and urban agricultural production system efficient [16].

On the other hand, in figure 11 it can be seen that there is a greater level of difference between roast 4 compared to roast 5 with the highest contrast statistic, thus the level of significance is less than 0.05 margin of error to accept the hypothesis that there is a significant difference between these two curves. The system provides control over the rate of temperature rise from 3 to $20^{\circ} \mathrm{C} / \mathrm{min}$.

\section{Conclusions}

The implementation of the engineering method for the mechanical design of the fluid bed system, using CAD software, allowed to analyze important physical parameters in the system such as air flow and energy transfer in such a way that it was possible to know a real approximate behavior validated later Through experimental tests, in addition, make the pertinent modifications to optimize the amount of energy and resources required.

In the control processes, the precision and quality of the roaster covers the range of 3 to $20^{\circ} \mathrm{C} / \mathrm{min}$, which is highly important since the precision and response speed of the controller are affected by these variables. However, using digital control techniques implemented in this work, it was possible to refine the operation of the controllers to obtain optimal performance even with the use of entry-level sensors and actuators, which poses an advantage to be able to offer products with a control system. Control for both the expert roaster and small coffee growers that allow training in the processing and obtaining of specialty coffees and thus take advantage of the added value of this process to increase profits and improve the living conditions of their families.

It became clear the need to develop a statistical analysis method that takes into account the cumulative error present due to the low precision of the implemented temperature sensor, since the operating principles of the toaster do not match existing methods or which prevents studies that allow to optimally evaluate the operation of the controller.

\section{Acknowledgments}

Thanks to Technological Park of Coffee InnovationTECNiCAFÉ, Tecnoparque SENA, Popayán node, the $\mathrm{PhD}$ in Electronics Sciences-Unicauca and the 
Comfacauca University- Unicomfacauca. GISI research group.

\section{References}

[1] E. Vargas, et al., "Avaliação da homogeneidade da expansão dos grãos de café torrados", VIII Simpósio de Pesquisa dos Cafés do Brasil, 2013. Available at: http://www.sbicafe.ufv.br:80/handle/123456789/33 96

[2] A. Giraldo Cerón, "Tan cerca y tan lejos de la agricultura 4.0 en Colombia", Revista Universidad EAFIT, vol. 55, no. 175, pp. 78-85. 2020.

[3] O. Ocampo López, L. Álvarez-Herrera, "Tendencia de la producción y el consumo del café en Colombia", $A d C$, vol. 36, no. 64, pp. 139-165, 2017. https://doi.org/10.19053/01203053.v36.n64.2017.5 419

[4] G. Puerta, "Composición química de una taza de café. Avances Técnicos Cenicafé”, pp. 1-12, 2011. [online]. Available at: https://biblioteca.cenicafe.org/handle/10778/340

[5] H. Samodro, et al., "Maintaining the Quality and Aroma of Coffee with Fuzzy Logic Coffee Roasting Machine", IOP Conference Series: Earth and Environmental Science, vol. 426, no. 1, 2020. https://doi.org/10.1088/1755-1315/426/1/012148

[6] R. A. Fadri, et al., "Review of coffee roasting process and formation of acrylamide related to health", Journal of Applied Agricultural Science and Technology, vol. 3, no. 1, pp. 129-145, 2019. https://doi.org/10.32530/jaast.v3i1.82

[7] S. Botero Lopez, and M. Salman Chaudhry, "Designing an Efficient Supply Chain for Specialty Coffee from Caldas-Colombia", 2020. [Online]. Available at: https://ctl.mit.edu/pub/thesis/designing-efficientsupply-chain-specialty-coffee-caldas-colombia

[8] J. A. Suarez-Peña, et al., "Machine Learning for Cup Coffee Quality Prediction from Green and Roasted Coffee Beans Features", Workshop on
Engineering Applications, Springer, Cham, 2020. https://doi.org/10.1007/978-3-030-61834-6_5

[9] S. Putra, et al., "Theoretical study of fluidization and heat transfer on fluidized bed coffee roaster", AIP Conference Proceedings, vol. 2097, no. 1, AIP Publishing LLC, https://doi.org/10.1063/1.5098287

[10] O. Benítez, D. Campo-Ceballos, "Evaluación de la calidad el café tostado utilizando herramientas de procesamiento digital de imágenes", $A C C B$, vol. 1, no. 30, pp. 32-43, 2018.

[11] V. Meana, et al., "Design, Fabrication, and Performance Evaluation of a Batch-Type Fluidized Bed Coffee Roaster for Small-Scale Coffee Growers", Mountain Journal of Science and Interdisciplinary Research, vol. 79, no. 2, 90-97, 2019.

[12] L. D. Buesaquillo Imbaquingo, "Sistema de control para mejorar el desempeño de una máquina tostadora de café", tesis, Universidad Técnica del Norte, Ecuador, 2019.

[13] M. A. Fonseca Villamil, C. H. Mesa Mesa, "Modelo logístico de recolección de llantas para la ciudad de Tunja”, Revista vínculos, vol. 14, no. 2, pp. 108118, dic. 2017. https://doi.org/10.14483/2322939X.13196

[14] A. Ghani, N. Hamizah, "Development of a novel 2D single coffee bean model and comparison with a $3 \mathrm{D}$ model under varying heating profiles", Journal of Food Process Engineering, vol. 42, no. 4, 2019. https://doi.org/10.1111/jfpe.13063

[15] D. Campo-Ceballos, et al., "Herramientas de CV para evaluar el color y matiz del café tostado: el color del café tostado y su relación con las propiedades organolépticas", Editorial Académica Española, 2018.

[16] J. D. Rodríguez, N. F. Sanabria, A. Chacón García, "Control de temperatura y humedad para cultivo de hongos comestibles shiitake", Visión Electrónica, vol. 6, no. 1, pp. 104-114, 2012. 